\title{
Habitat alteration enables hybridisation between Lesser Spotted and Greater Spotted Eagles in north-east Poland
}

\author{
GRZEGORZ MACIOROWSKI and PAWEŁ MIRSKI
}

\section{Summary}

Wetlands in the Biebrza Valley, north-east Poland, are inhabited by two closely related Aquila species: the more numerous Lesser Spotted Eagle A. pomarina prefers human-transformed landscapes, whereas the very rare Greater Spotted Eagle A. clanga is associated with natural marshy landscapes. At least since the last decade of the $20^{\text {th }}$ century, these two species have been known to hybridise in the broad zone of their sympatric occurrence in Europe. The aim of the present study was to compare habitat preferences of both spotted eagle species in order to detect which environmental factors could increase the probability of hybridisation. We analysed nesting and hunting habitats for 148 breeding territories (61 of A. pomarina, 56 of A. clanga and 31 of mixed pairs). As expected, the presence of breeding Greater Spotted Eagles was associated with non-transformed marshy landscapes, whereas Lesser Spotted Eagles clearly preferred humantransformed areas. We hypothesised that mixed pairs should occur in intermediate habitat, confirming this assumption by analysing several variables: distance to human settlements, distance to open areas, and proportion of wetlands, shrublands, grasslands, agricultural mosaic and arable land. Results of this study suggest that some landscape changes can enable two species with different habitat requirements to inhabit the same area and hybridise. This scenario has potential conservation implications for the rarer species, Greater Spotted Eagle, which has narrower habitat preferences.

\section{Introduction}

The Lesser Spotted Eagle Aquila pomarina (hereinafter LSE) is listed as 'Least Concern' by IUCN, and occurs in central, eastern and south-eastern Europe (Meyburg et al. 2001). In Poland, its population size is at least $1,800-2,000$ breeding pairs (Cenian et al. 2006). LSE occurs across approximately $30-40 \%$ of Poland (Rodziewicz et al. 2007). The Greater Spotted Eagle Aquila clanga (hereinafter GSE) is much rarer, with 'Vulnerable' IUCN status. In Poland, it occurs almost exclusively in the Biebrza Valley, with a population of $13-15$ pairs (Maciorowski unpubl. data), reaching the western border of its breeding range. Both closely related eagle species occur in the Biebrza valley, but the population size of LSE in this area (30-35 pairs) is approximately twice that of GSE (Maciorowski unpubl. data). Both GSE and LSE build their nests in forest edges and they tend to hunt across open ground (Cramp and Simmons 1980, Dombrovski et al. 2000). There are a number of important differences in habitat selection between the two species. GSE prefers marshes, whereas LSE avoids marshes and hunts more often over semi-natural, extensively farmed areas (Cramp and Simmons 1980). In the Biebrza Valley, where they are sympatric, there is little published information, but Pugacewicz (1995) observed that GSE tended to select areas which were more overgrown by reeds and bushes and were wetter compared to LSE hunting sites. 
Also, GSE hunted in the flood zone of the Biebrza river more frequently than LSE. A detailed description of the breeding habitat of these two species has only been published for Estonia (Lõhmus and Väli 2005), but differences were not significant. Habitat selection of LSE, which is a much more common species in Europe, has been well studied, mainly in respect to their breeding and foraging habitat (Treinys 2004, Lõhmus \& Väli 2005, Mirski 2009, Zub et al. 2010) including macrohabitat scale studies (Väli et al. 2004). LSE elsewhere in Europe strongly selects grasslands, placing nests close to open landscapes with a significant proportion of the nests built in spruce Picea spp. In some studies, LSE avoided placing nests near man-made infrastructure.

Some dietary differences can also be pointed out. LSE mostly prefers small prey (e.g. voles, passerines and frogs; Treinys and Dementavičius 2004, Zub et al. 2010), while GSE prefers medium sized prey (e.g. ducks, waders, rails and water voles Arvicola amphibius, if available; Väli and Lõhmus 2002, Dombrovski 2010, Maciorowski 2013).

The importance of studying habitat preferences of the GSE has been strongly emphasised (Meyburg et al. 2001) due to increasing hybridisation between the two species, which leads to a decline in the number of pure GSE breeding pairs. The threat to the persistence of GSE populations due to introgressive hybridisation with LSE has been documented in several countries, including Estonia, Poland, Belarus and Lithuania (Bergmanis et al. 1997, Lõhmus \& Väli 2001, Dombrovski 2005, Meyburg et al. 2005, Treinys 2005). In addition, detailed molecular analyses have also revealed cases of hybridisation in Germany (only one individual in a mixed pair) and in the European part of Russia (Väli et al. 2010). In the Biebrza Valley, mixed GSE and LSE pairs can currently comprise up to half of all GSE pairs (Maciorowski and Mizera 2010) while in the rest of the country in recent years only $2-3$ mixed breeding pairs have been recorded (Aftyka, Mirski, Pugacewicz unpublished data).

Except for hybridisation, an important factor affecting the population decline of GSE in the Biebrza Valley is loss of its optimal foraging sites (Väli and Lõhmus 2002, Meyburg et al. 2001, Maciorowski et al. 2005). The external part of the valley was drained in the 1960s and earlier, and today it is used relatively intensively for meadows and pastures. This has caused a decrease in groundwater level and changes in vegetation structure, strongly affecting the feeding resources of GSE.

Hybridisation and habitat loss are most likely to be mutually related. Wetland habitat transformation into anthropogenic grassland probably favours only LSE. The Biebrza valley offers breeding sites for GSE, LSE and mixed pairs, thus creating an exceptional opportunity to study habitat selection of the two species. The aim of this study was to identify whether there was a pattern of habitat change that eliminated ecological barriers for mating between these species and leads to their subsequent hybridisation. Identifying types of habitat optimal for GSE and suboptimal for both species will allow conservation action to improve habitats that are preferred by GSE.

\section{Methods}

\section{Study area}

Eagles in Kotlina Biebrzańska (Biebrza Valley), one of the largest areas of fen mire in central Europe, have been studied annually since 1990. Overall, the study area consists of 191,250 ha of various habitat types, of which over $52 \%$ (100,00o ha) are fens, and $36 \%(68,585$ ha) is covered by forests. A distinctive feature of the valley is a very high cover of marsh forest habitats, typically wet alder forests and marsh birch forests, which together constitute $36.7 \%$ of all forest stands in the valley. In the wettest part, the lower Biebrza basin, the cover of marshy deciduous forest stands is even higher (56.6\%) (Bosiak 1991). High marsh vegetation (mostly sedges, such as Carex acuta, C. elata, C. appropinquata and other plants, such as Glyceria maxima, Calamagrostis canescens ) has on many sites been replaced by habitats with low vegetation, intersected by ditches and drainage channels - mostly meadows with low species diversity, mown 2-3 times per year, or less often with pastures grazed by cattle. 
In the more remote parts of Biebrza Basin, that are under natural water regimes, water voles and medium sized birds (e.g. ducks, waders and rails) are considerably more abundant than in the drained parts, which have been converted into managed grasslands. Conversely, the common vole Microtus arvalis and small passerines like skylarks Alauda arvensis and pipits Anthus spp. are more abundant and more accessible during periods in which the grass is mown.

\section{Data collection}

Between 1990 and 2010, nests of eagles in the Biebrza Valley were located and monitored. Using information from simultaneously occupied nests and territorial behaviour, borders of territories were identified. All territories were located and nearly all nests of GSE in the Biebrza Valley were found. In the case of LSE and mixed breeding pairs, approximately $80 \%$ of nests and territories were identified. In total 148 nests and 83 breeding territories of GSE, LSE and mixed GSE and LSE pairs were included in the analysis (Table 1 ). Data for each of these three categories were analysed separately.

Since 2000, nest coordinates were recorded with a GPS. Earlier nest locations were recorded on forest stand maps at the scale of 1:10 ooo and then digitised. Analysis of breeding forest stand habitats were performed in ArcGis 9.3 using forest maps of the Biebrza National Park and the Rajgród Forest Division and 1:50 ooo topographic maps. For each nest, the distances (in metres) to the nearest built-up area, open area, natural watercourse and drainage channel were measured. In addition, the age of the trees at the nest site was determined using tree stand maps.

Next, habitats surrounding the nest site tree stand and hunting areas of individual breeding pairs were analysed. Two-km radius zones were drawn around the centre of each breeding territory. Centres were established as the centroid of the shape created by drawing a polygon around neighbouring known nests of a given pair in each territory. The distance of $2 \mathrm{~km}$ is considered to be the average diameter of territories of the eagles in central and eastern Europe according to telemetry data (Scheller et al. 2001) and has been applied in other studies (Treinys 2004, Väli et al. 2004, Mirski 2009).

Buffer zones around nests and random points were placed over a layer containing types of land cover, according to the Corine Land Cover system. Land cover data were collected in 2006 using satellite photographs of spatial pixel resolution equal to 25 ha. Within each buffer zone, the area of each land use category was calculated, yielding 11 types of land use present in the study area. All forest types (coniferous, deciduous, mixed) were pooled into one category. Two other land use categories: farmland mosaic and farmland with a significant proportion of natural vegetation were combined into the category 'agriculture mosaic'. Water bodies were found in less than $4 \%$ of all analysed buffer zones, making up on average less than $1 \%$ of the total buffer zone area. As a result, they were excluded from further analyses. Hence, seven categories of land cover were present: artificial surfaces, arable land, grasslands, agriculture mosaic, forest, shrubland, and wetlands. The distances from watercourses, built-up areas and open areas were log-transformed and the areas of each land cover category were arcsine-transformed prior to statistical analysis. Raw data were used to draw box-plot graphs.

Table 1. Variables measured and sample size of the breeding Greater (GSE) and Lesser (LSE) Spotted Eagles studied.

\begin{tabular}{lllll}
\hline & \multicolumn{4}{l}{ Number of samples } \\
\cline { 2 - 5 } Factor & GSE & Mixed pairs & LSE & Random \\
\hline Distances from nests to landscape elements & 56 & 31 & 61 & 70 \\
Forest stand age & 51 & 23 & 45 & 67 \\
Ground cover in foraging territories & 20 & 14 & 49 & 50 \\
\hline
\end{tabular}


The habitat variables were then tested using isotonic regression (Gaines and Rice 1990) in Rundom Pro 3.14 (Jadwiszczak 2009). This test is a non-parametric approach for fitting monotonic models to data when a directional pattern in variables is expected. The expected pattern in our study was: GSE - mixed pairs - LSE, or the opposite, depending on the variable tested. This pattern assumes that GSE is the most specialised species (see Pugacewicz 1995, Dombrovski \& Ivanovsky 2005, Lõhmus \& Väli Ü. 2005, Dombrovski 2012) which: (I) to the highest extent avoids breeding in the vicinity of human settlements; (2) selects areas located deeper in the forest and less accessible for man; (3) utilises areas located the closest to the river bed (the source of spring floods); (4) nests in the oldest tree stands; (5) avoids urbanised areas, arable and forest land; meadows and pastures and farmland mosaics as they are not the most attractive foraging areas; and (6) shows preference for marsh areas and highly natural habitats, such as shrubland and wetland. In accordance with the above assumptions, LSE would behave in an opposite manner to GSE and mixed pairs would select intermediate habitat types.

In addition, in order to assess the strength of habitat preference of GSE, LSE and mixed pairs, 70 random points were sampled in the forests of the Biebrza Valley and analogous distance analysis carried out. A similar analysis was performed to assess the strength of preference for land cover categories, using 50 random points. Differences in each habitat variable between the nest sites and random points were tested using the Mann-Whitney U-test with Statistica 9.

\section{Results}

Two of the four studied variables were consistent with our predictions (Table 2). In the case of the two remaining variables, differences in habitat preferences were seen between GSE and LSE but mixed pairs did not match the predicted pattern (Figure $1 \mathrm{~b}, \mathrm{Id}$ ).

Nests of both eagle species were placed closer to open areas than would be expected from a random distribution (Table 3). Those closest to open areas were nests of LSE, then mixed pairs and GSE nested the furthest from open areas, which followed our expectations (Figure 1a). Only GSE nested closer to natural watercourses than would be expected from a random distribution (Table 3). Our predictions were not confirmed since mixed pairs nested further from watercourses than LSE (Table 2, Figure $1 \mathrm{~b}$ ). The nests of GSE were clearly the furthest from human settlements (Figure Ic) and the predicted differences in the expected preference gradient were statistically significant (Table 2). Distance of nests of mixed pairs from buildings appeared to follow a random distribution and LSE nests were closer to human settlements. However, these differences were not statistically

Table 2. Habitat measures in the gradient of expected preference of the spotted eagles (see assumptions in the Methods section) tested with isotonic regression. See Table 1 for the number of samples used to test each factor.

\begin{tabular}{llll}
\hline & & \multicolumn{2}{c}{ Isotonic regression results } \\
\cline { 3 - 4 } Factor & Expected direction & $\mathrm{E}$ & $P$ \\
\hline Distance to settlements & $>$ & 0.1573 & $<0.001$ \\
Distance to open areas & $<$ & 0.0952 & $<0.001$ \\
Distance to rivers & $<$ & 0.0153 & $\mathrm{~ns}$ \\
Forest-stand age & $<$ & 0.0257 & $\mathrm{~ns}$ \\
Share of artificial surfaces & $<$ & 0.0271 & $<0.05$ \\
Share of arable land & $<$ & 0.0498 & $<0.05$ \\
Share of grasslands & $<$ & 0.0498 & $<0.01$ \\
Share of agriculture mosaic & $>$ & 0.0184 & $\mathrm{~ns}$ \\
Share of forest & $>$ & 0.0000 & $<0.01$ \\
Share of shrubland & & 0.1880 & $<0.0001$ \\
Share of wetlands & & 0.2857 & \\
\hline
\end{tabular}



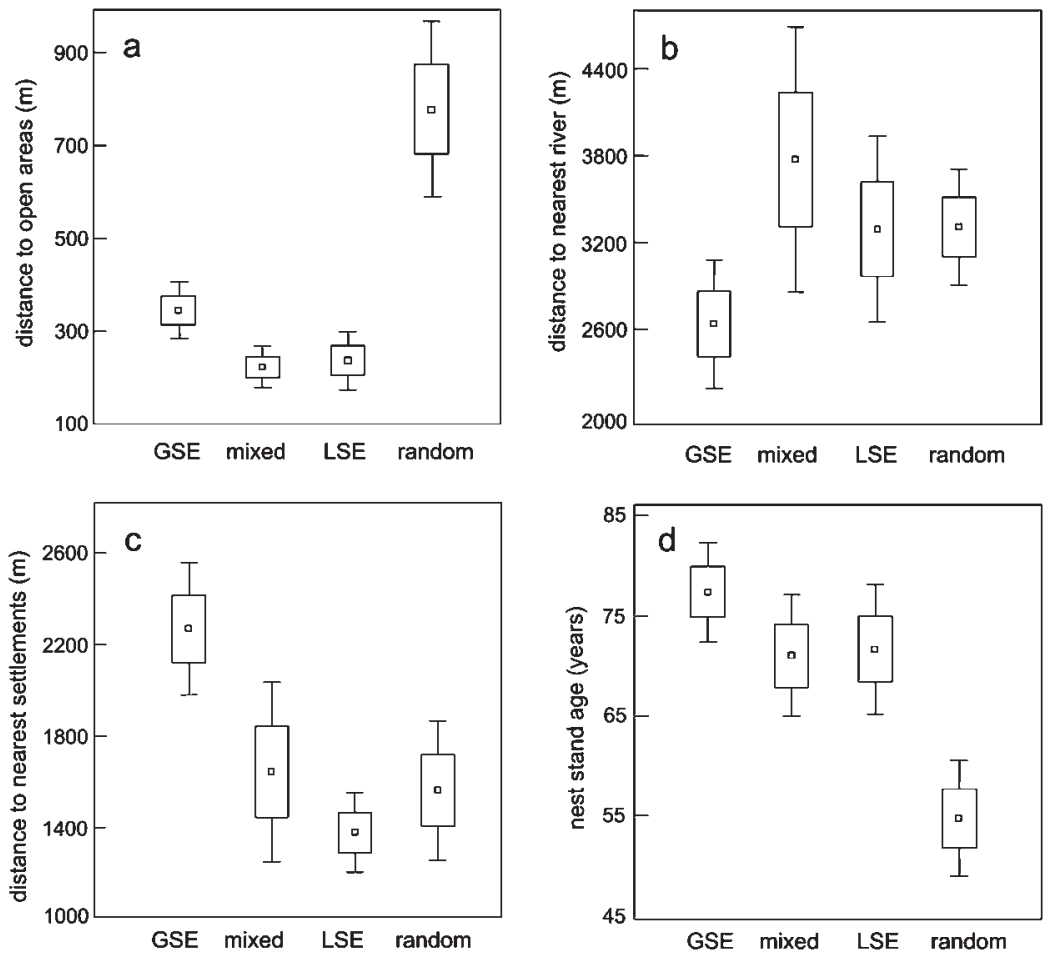

Figure 1 . Box plots (mean, standard error, $95 \%$ confidence interval) of the nest site characteristics in Greater (GSE) and Lesser (LSE) Spotted Eagles. a) mean distance to forest edge, b) nearest river, c) nearest settlements and d) nest stand age.

significant (Table 3). The oldest tree stands were used by GSE and the youngest ones by LSE and mixed pairs (Figure Id). The differences between these gradient categories were not statistically significant (Table 2), but when tested separately, LSE, GSE and mixed pairs all showed preference for older tree stands (Table 3 ).

Table 3. Habitat selection by Greater (GSE) and Lesser (LSE) Spotted Eagles. Differences in distances from nests and random points to various landscape elements and share of the land cover in 2-km radius were compared using the Mann-Whitney U-test.

\begin{tabular}{|c|c|c|c|c|c|c|}
\hline & \multicolumn{2}{|c|}{ GSE vs random } & \multicolumn{2}{|c|}{ Mixed vs random } & \multicolumn{2}{|c|}{ LSE vs random } \\
\hline & $\mathrm{U}$ & $P$ & $\mathrm{U}$ & $P$ & $\mathrm{U}$ & $P$ \\
\hline Distance to settlements & 1160 & $<0.001$ & 966 & ns & 2071 & ns \\
\hline Distance to open areas & 1537 & $<0.05$ & 676 & $<0.01$ & 1193 & $<0.0001$ \\
\hline Distance to rivers & 1487 & $<0.05$ & 1022 & ns & 1861 & ns \\
\hline Forest-stand age & 770 & $<0.0001$ & 404 & $<0.001$ & 943 & $<0.0001$ \\
\hline Share of artificial surfaces & 435 & $<0.05$ & 307 & ns & 1046 & ns \\
\hline Share of arable land & 355 & ns & 293 & ns & 1038 & ns \\
\hline Share of grasslands & 495 & ns & 342 & ns & 807 & $<0.01$ \\
\hline Share of agriculture mosaic & 480 & ns & 261 & ns & 748 & $<0.001$ \\
\hline Share of forest & 402 & ns & 227 & $<0.05$ & 928 & $<0.05$ \\
\hline Share of shrubland & 359 & ns & 230 & $<0.05$ & 873 & $<0.05$ \\
\hline Share of wetlands & 370 & ns & 336 & ns & 916 & $<0.05$ \\
\hline
\end{tabular}


Foraging areas of GSE, LSE and mixed pairs were significantly different with regard to some land cover categories (Figure 2). Five of the seven variables were found to match our assumptions (Table 2). For GSE, the key foraging sites were natural ecosystems such as marshes and shrubland, and mixed pairs were in line with our predictions as they used habitats intermediate between GSE and LSE (Figure $2 a, 2 b$ ). A reverse trend was recorded in the case of habitats altered by man. GSE avoided farmland mosaics, arable land, meadows and pastures but these categories comprised a substantial part of LSE territories (Figure $2 \mathrm{c}, 2 \mathrm{~d}, 2 \mathrm{e}$ ). In the case of mixed pairs, a majority of the studied variables showed a pattern matching our expectations. Their foraging sites were mostly similar to those of GSE. They resembled foraging sites of LSE only in the case of the grasslands category (Table 2, Figure 2e). GSE foraging sites were not significantly different from a sample of habitats in the Biebrza Valley, except for a lower percentage of artificial surfaces relative to the random buffer zones (Table 3). Foraging sites of mixed pairs were also not significantly different from the baseline conditions in the Biebrza Valley. Only shrubland was found to be chosen selectively and highly forested areas tended to be avoided (Table 3, Figure 2). The strongest habitat preference was observed in LSE, which clearly selected farmland patches with a high percentage of grassland and agriculture mosaic, as well as of arable land, which however was not statistically different from the amount of arable land in random buffer zones. Finally, LSE clearly avoided areas covered by shrubs, wetlands and highly afforested areas (Table 3 ).

\section{Discussion}

Our results show a significant variation in habitat preferences between LSE and GSE, which are sympatric in the Biebrza Valley. Occurrence of GSE in areas that are wetter and have more shrubs than those occupied by LSE is consistent with earlier observations of habitat preference of these two species in the Biebrza Valley (Pugacewicz 1995) and in Belarus (Ivanovsky 1996, Dombrovski and Ivanovsky 2005). Similarly, the observed habitat preferences of LSE agree with the results obtained by other authors, mainly with respect to the strong preference for grassland and nesting close to open areas (Treinys 2004, Mirski 2009, Zub et al. 2010). Distance to the closest buildings was comparable in all studies and percentage of arable land on LSE territories in the Biebrza Valley was even lower. This stems from the fact that the valley is less populated and wetter than other similar areas in Poland.

Preferences for wetlands and natural and more remote, habitats in GSE may be explained, at least partly, by higher occurrence of birds, like Spotted Crake Porzana porzana, Snipe Gallinago gallinago and Corncrake Crex crex, which are favoured by this species in Biebrza Valley (Maciorowski 2013). Both LSE and mixed pairs showed a different preference for managed grasslands. LSE, in the lowlands of north-east Poland, prefers to hunt on small rodents, mostly voles (Zub et al. 2010) and is able to capture them effectively in low vegetation (Mirski 2010) and so prefers habitats where these prey are more accessible. In case of mixed pairs, almost all of them are formed by LSE male with GSE female. Taking into consideration that the male is the main food supplier for the chick and the female in the first half of breeding period male habitat preferences may be crucial for territory selection.

Our hypothesis that mixed pairs occupy habitats suboptimal for GSE was confirmed for a majority of variables analysed. The habitats utilised as hunting areas by mixed pairs were mainly located on dried and drained marshes, with habitat intermediate between the natural marsh vegetation and farmland of a river valley. In a similar study carried out in Estonia, differences between GSE and mixed pair habitats were not found to be significant. The authors suggest that mixed pairs use the habitats of GSE that are not taken by pure GSE pairs due to the low population size on the edge of their geographic range (Lõhmus and Väli 2005). However, data collected in the Biebrza Valley indicates that GSE habitats do not match the requirements of LSE. It is very likely that differences between habitat preferences between GSE and mixed pairs were not found in Estonia due to a small sample size. 

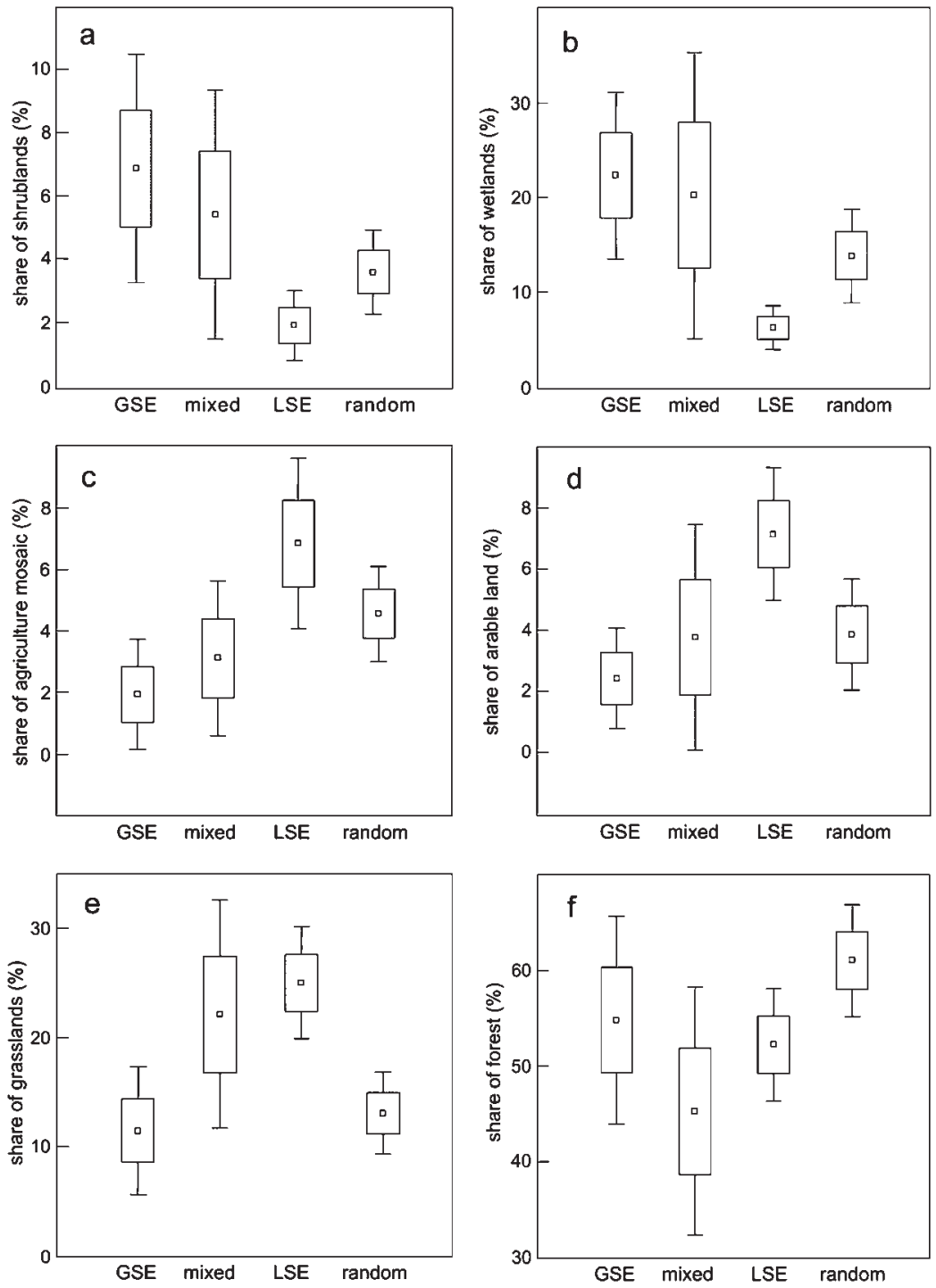

Figure 2. Box plots (mean, standard error, $95 \%$ confidence interval) of the landscape characteristics in foraging grounds (2-km radius from nests and random points) in Greater (GSE) and Lesser (LSE) Spotted Eagles. a) share of shrublands, b) wetlands, c) agriculture mosaic, d) arable land, e) grasslands and f) forest.

Similar niche divergence has been recorded in two other birds of prey. For instance, spatial segregation was observed in hawk-eagles on Java in Indonesia. Spizaetus bartelsi and S. cirrhatus were found to be spatially segregated by habitat type and altitude. Still, partial overlap of their niches was seen, which most probably was caused by anthropogenic factors, since natural rainforests were replaced with a tree stand with looser structure resulting from tree stand transformation (Nijman 2004). However, two species can co-occur in one area and their ecological niches can overlap to a great extent, as is the case with two hawk species, Swainson's Hawk Buteo swainsoni 
and Red-tailed Hawk B. jamiacensis (Bosakowski et al. 1996). This might be a likely reason for the observed hybridisation between these two species (Hull et al. 2007), as in the case of Aquila eagles.

Some authors doubt that habitat alteration may favour hybridisation, pointing to a low number of published studies documenting this mechanism and the fact that hybridisation occurs both in disturbed and undisturbed habitats (McCarthy 2006). However, in the case of GSE, despite its broad breeding range, populations are not continuous and occur in patchy environments. The hybridisation zone of the eagles is at least $1,700 \mathrm{~km}$ wide (Väli et al. 2010) but occurrence of GSE is usually restricted to small populations in marsh habitats, whereas LSE is much more numerous and more widespread in this zone. Our study provides evidence for the hypothesis that mating between these two species takes place in habitats disturbed to the extent that they are intermediate in terms of the two species' requirements. The increasing hybridisation between the two eagle species may result from elimination of an ecological barrier, which earlier could have triggered their divergence, in accordance with the speciation along environmental gradients model (Doebeli and Dieckmann 2003). Adaptive speciation most likely led to the rise of two similar species with different habitat preferences. GSE is a species adapted to habitats with natural marsh vegetation whereas LSE prefers anthropogenic farmland. Landscape changes, such as drainage of marshes and their utilisation for farming, allow the more numerous LSE population to encroach into habitats that up to now were taken by GSE. This creates a real threat of extinction to GSE in this area, through gradual genotype dilution caused by increasing hybridisation, which is enabled by transformation of marsh habitats.

\section{Acknowledgements}

The study was conducted as part of the LIFEo8 NAT/PL/Ooo511 AQC Plan "Securing the population of Aquila clanga in Poland: preparation of a National Action Plan and primary site conservation", funded by the European Commission LIFE+ National Fund for Environmental Protection and Water Management, and the Regional Fund for Environmental Protection and Water Management in Białystok. We would like to thank all the people involved in field studies on GSE in the Biebrza Valley in the past 20 years: Baranowski P., Bartoszuk K., Batycki A., Białek M., Graszynski K., Henel K., Jankowski M., Kasprzak A., Kowalski J., Lontkowski J., Matthes J., Meyburg B., and Mizera T. We are also grateful to Przemysław Chylarecki and an anonymous reviewer for valuable comments on our work and Piotr Jadwiszczak for statistical advice connected with isotonic regression.

\section{References}

Bergmanis, U., Petrinš, A., Strazds, M. and Krams, I. (1997) Possible case of hybridization of the Lesser Spotted eagle and the Greater Spotted eagle in Eastern Latvia. Putni Daba 3: 2-6.

Bosakowski, T., Ramsey, D. and Smith, D. G. (1996) Habitat and spatial relationships of nesting Swainson's hawk (Buteo swainsoni) and red-tailed hawks (B. jamaicensis) in Northern Utah. Great Basin Nat. 56: $341-347$.

Bosiak, A. (1991) Forests of Biebrza Valley. Zesz Problem Postępów Nauk Roln 372: 522-535. (In Polish).
Cenian, Z., Kalisiński, M., Kapowicz, R., Rodziewicz, M., Stój, M. and Wójciak, J. (2006) Situation and conservation status of Lesser Spotted Eagle Aquila pomarina in Poland at the turn of the XX and XXI century. Studia i Mat CEPL 12: 149-154. (In Polish).

Cramp, S. and Simmons, K. E. L., eds. (1980) The birds of the Western Palearctic, 2. Oxford: Oxford University Press.

Doebelli, M. and Dieckmann, U. (2003) Speciation along environmental gradients. Nature 421: 259-264. 
Dombrovski, V. (2005) Hybridation entre Aigles criard Aquila clanga et pomarin $A$. pomarina en Biélorussie: conséquence taxonomique. Nos Oiseaux 52: 27-30.

Dombrovski, V. (2010) The diet of the greater spotted eagle (Aquila clanga) in Belarusian Polesie. Slovak Rapt. J. 4: 23-36.

Dombrovski, V. (2012) National action plan for Greater Spotted Eagle conservation in Belarus. Minsk: The National Academy of Sciences of Belarus.

Dombrovski, V. and Ivanovsky, V. (2005) Number, distribution and breeding ecology of the Greater Spotted Eagle (Aquila clanga) in Belarus. Ornithologia 32: 56-69.

Dombrovski, V. C., Tishechkin, A. K., Zhuravliov, D. V., Dmitrenok, M. G. and Pinchuk, P. V. (200o) Breeding records of Greater Spotted Eagle (Aquila clanga) in Central Polesie. Subbuteo 3: 3-13.

Gaines, S. D. and Rice, W. R. (1990) Analysis of biological data when there are ordered expectations. Am. Nat. 135: 310-317.

Hull, J. M., Savage, W. K., Smith, J. P., Murphy, N., Cullen, L., Hutchins, A. C. and Ernest, H. B. (2007) Hybridization among Buteos: Swainson's hawk (Buteo swainsoni) $\mathrm{x}$ red-tailed hawk (Buteo jamaicensis). Wilson J. Ornithol. 119: 579-584.

Ivanovsky, V. (1996) Notes on the breeding biology of spotted eagles Aquila clanga and A. pomarina in Byelorussia. Pp. 297-299 in B.-U. Meyburg and R. D. Chancellor, eds. Eagle studies. Berlin, Germany, London, UK and Paris, France: World Working Group on Birds of Prey and Owls.

Jadwiszczak, P. (2009) Rundom Pro 3.14. Software for classical and computer-intensive statistics. www.pjadw.tripod.com. Accessed January 2011.

Lõhmus, A and Väli, Ü. (2001) Interbreeding of the Greater Aquila clanga and Lesser Spotted Eagle A. pomarina. Acta Ornithoecol. 4:377-384.

Lõhmus, A., and Väli, Ü. (2005) Habitat use by the Vulnerable greater spotted eagle Aquila clanga interbreeding with the lesser spotted eagle Aquila pomarina in Estonia. Oryx 39: 170-177.

Maciorowski, G. (2013) Results of diet analysis basing on CCTV observation of the Aquila clanga nests. In: P. Mirski, ed. Conservation of the Greater Spotted Eagle. Proceedings of the International Workshop, Goniądz, Poland.

Maciorowski, G. and Mizera, T. (2010) Conservations and studies on Greater Spotted Eagle in Poland - LIFE project. Studia i Mat CEPL 25: 181-190 (In Polish).

Maciorowski, G., Mizera, T. and Meyburg, B.-U. (2006) Occurrence and conservation of the Greater Spotted Eagle Aquila clanga in Biebrza Valley. Studia i Mat CEPL 12: 105-114. (In Polish).

McCarthy, E. M. (2006) Handbook of avian hybrids of the world. New York: Oxford University Press.

Meyburg, B.-U., Haraszthy, L., Strazds, M. and Schaffer, N. (2001) European Species Action Plan for Greater Spotted Eagle (Aquila clanga). In N. Schäffer and U. Gallo-Orsi, eds. European Union action plans for eight priority bird species. Luxembourg: European Commission.

Meyburg, B.-U., Mizera, T, Matthes, J, Graszynski, K, Schwanbeck, J. P. and Maciorowski, G. (2005) Hybridization of Greater Aquila clanga and Lesser Spotted Eagle A. pomarina in Poland and Germany. Pp. 115-117 in T. Mizera and B.-U. Meyburg, eds. International meeting on Spotted Eagles (Aquila clanga, A. pomarina and A. hastata) research and conservation. Osowiec Twierdza, Poland: Biebrza National Park. (In Polish).

Mirski, P. (2009) Selection of nesting and foraging habitat by the Lesser Spotted Eagle Aquila pomarina (Brehm) in the Knyszynska Forest (NE Poland). Pol. J. Ecol. 57: 581-587.

Mirski, P. (2010) Effect of selected environmental factors on hunting methods and hunting success in the Lesser Spotted Eagle Aquila pomarina in north-eastern Poland. Russ. J. Ecol. 41: 197-200.

Nijman, V. (2004) Habitat segregation in two congeneric hawk-eagles (Spizaetus bartelsi and S. cirrhatus) in Java, Indonesia. J. Trop. Ecol. 20: 105-111.

Pugacewicz, E. (1995) Population of the Spotted Eagle (Aquila clanga) in the Biebrza marshes in 1989-1993. Not. Orn. 36: 311-321. (In Polish).

Rodziewicz, M., Stój, M., Wójciak, J. and Kalisiński, M. (2007) Lesser Spotted Eagle 
Aquila pomarina. Pp. 152-153 in A. Sikora, Z. Rohde, M. Gromadzki, G. Neubauer and P. Chylarecki, eds. The atlas of breeding birds in Poland 1985-2004. Poznań, Poland: Bogucki Wydawnictwo Naukowe. (In Polish). Scheller, W., Bergmanis, U., Meyburg, B.-U., Furkert, B., Knack, A. and Roper, S. (2001) Raum-Zeit-Verhalten des Shreiadlers (Aquila pomarina). Acta Ornithoecol 4: 75-236.

Treinys, R. (2004) Important landscape factors for the breeding territory selection by Lesser Spotted Eagle (Aquila pomarina). Acta Zool. Lit. 14: 58-61.

Treinys, R. (2005) The Greater Spotted Eagle Aquila clanga: previous, current status and hybridization in Lithuania. Acta Zool. Lit. 15: 31-38.

Treinys, R. and Dementavičius, D. (2004) Productivity and diet of the Lesser Spotted Eagle (Aquila pomarina) in Lithuania in 2001-2003. Acta Zool. Lit. 14: 83-87.
Väli, Ü. and Lõhmus, A. (2002) Parental care, nestling growth and diet in a Spotted Eagle Aquila clanga nest. Bird Study 49: 93-95.

Väli, Ü., Treinys, R. and Lõhmus, A. (2004) Geographical variation in macrohabitat use and preferences of the Lesser Spotted Eagle Aquila pomarina. Ibis 146: 661-671.

Väli, Ü., Dombrovski, V., Treinys, R., Bergmanis, U., Daróczi, S., Dravecky, M., Ivanovsky, V., Lontkowski, J., Maciorowski, G., Meyburg, B. U., Mizera, T., Zeitz, R. and Ellegren, H. (2010) Wide-spread hybridization between the Greater Spotted Eagle Aquila clanga and the Lesser Spotted Eagle Aquila pomarina (Aves: Accipitriformes) in Europe. Biol. J. Linn. Soc. 100: 725-736.

Zub, K., Pugacewicz, E., Jędrzejewska, B. and Jędrzejewski, W. (2010) Factors affecting habitat selection by breeding Lesser Spotted Eagles Aquila pomarina in northeastern Poland. Acta Ornithol. 45: 105-114.

\section{GRZEGORZ MACIOROWSKI}

Zoological Department, Poznań University of Life Science, Wojska Polskiego 71c, 60-625 Poznań, Poland.

\section{PAWEE MIRSKI*}

Institute of Biology, University of Białystok, Świerkowa 20B, 15-950 Białystok, Poland.

*Author for correspondence; e-mail:p.mirski@uwb.edu.pl

Received 29 September 2012; revision accepted I March 2013; Published online 28 August 2013 